\title{
LANDSCAPE ARCHITECTURE AND THE QUALITY OF LIFE \\ THE STORY OF RELATIVITY WITHIN THE \\ TRANSITIONAL SETTLEMENTS \\ TÁJÉPÍTÉSZET ÉS ÉLETMINŐSÉG
}

ÉLETMINŐSÉGI KÉRDÉSEK

\section{AZ ÁTMENETI TELEPÜLÉSEKEN}

\begin{tabular}{l} 
SZERZŐ/BY: \\
ANDREJA TUTUNDŽIĆ \\
\hline$\quad$ HTTPS://DOI.ORG/ \\
\hline $10.36249 / 52.1$
\end{tabular}

\section{ABSTRACT}

The quality of life and human wellbeing is often perceived differently, dependable on individuals and groups, as well as within contrasting sociopolitical circumstances, varying from the living stapla d bos as respecting the living standard based primarily on income to the benefits that

society receives from ecosystens. sional discipline beginings as a profeshas been respecting the quality of life and human well-being to a great exten as a subject of professional interest and accordingly, through approaches used to address it. While those goals are mostly the same, the engagement in the scope and complexity of the discipline is significantly increasing over the years, but still targeting the traditional paradigm - to contribute to the mprovement of the living conditions and quality of life. However, the majority of the projects are predominantly ealing with urban areas and the life of the urban population related to the pper- and middle-class social groups. Contrary to the above considerations, there is a layer of social groups of those who are forced to leave their homes in the times of crises, either caused by natural disasters, but even the poltiose secking sanctuary due to consers an be fond wose tragic events ities, sition heluding refugee camps or transitional settlements. Those places bring poor living conditions, lack of space, and numerous environment problems, where even just the prov sioning and supporting categories of ecosystem services are dependable on the input of external factors while regulating and cultural categories seems to be almost out of question. This paper describes the results of the "e-scape. Transitional settlement" Project, organized by the Department of Landscape Design and Ecosystem Management at American University in Beirut, in collaboration with the International Federation of Landscape Architecture. The goal of the project was to contribute to the improvement of the living conditions in the transitional settlements including the provision of even elementary the services in, at least, a bit greater extent The additional intention was to broaden a methodology and suidelines of la dscape architecturalintelines or wathe archinecturalinterfrom conflict and natural disasters.

Keywords: transitional settlements, ecosystem services, landscape archtecture, research by design

INTRODUCTION

The quality of life may be perceived in many ways. It is a broad multidimensional concept that usually includes subjective evaluations of both positive and negative aspects of life.' However it is often defined differently, by divergent individuals and groups, as well as within contrasting socio-political circumstances, since it is based on the perception which individuals have regarding their position in life in the context of the culture and value systems in which they live and in relation to their goals, expectations, stanards and concerns, according to the World Health Organisation (WHO). To make the matter more complex (or inane), during the past decades, globalisation imposed understanding of the quality of life with the concept of standard of living, based primarily on income and in some extent even within "appropriate" social status, as well.

Another similar term, introduced more recently, the well-being, is likewise widely used to describe perceptions of the lives of individuals and groups. As there is no single definition of hum well-being, it is useful to distinguish between the dimensions of subjective and objective well-being at a generalized level ${ }^{3}$ Well-being comprises not only material concerns but two further, interrelated dimensions: the relatione, representing the social and political processes which determine the distribution of costs and benefits, and a subjective dims jivitu social and and values which infuren

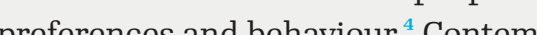
porary reserch goes much deeper poraty isserch goss much dowor (n) methods of quality of life indicators, as well as rather reliable quantitative measurements of well-being, which enables comparisons between social groups or geographical specificities. From another perspective, the qual of life and human well-being can be assessed trough the linkages betwee provision of ecosystem services, or the benefits that society receives from cosystems. ${ }^{5}$ "These linkages can be
1 The WHOQOL Group, 1998: The World Assessment (WHoposility of Life and psychometric properties. Soc Sci Med 46: pp. 1569 - 1585 . 2 WHOQOL: Measuring Quality of Life, tistics and information systems. wwo whoint/healthinfo/survey/whoqol-qualtyofilie/en/(retrieved 12 August 2019). sing the contribution of 2015. Asses. vices to human wellbeing: A disaggregated study in western Rwanda. Ecological Economics 117: 62-72. doi: 10.1016/j.ecolo 4 Gough $I$ McG being in developing countries: From Theory to Research, Cambridge UniCBO9780511488986 5 Chapin, E. S. 2013: Overview of Ecosystem Functions and Services. Their Impor rability: Understandin. Climate VulneThreats to Essential Resources, Vol 4, 3-11. doi: 10.1016/B978-0-12-384703- 
illustrated at all scales, from local to global; in all places in the world, fro the least to the most developed; and for all peoples, from the poorest to the wealthiest and the rural to the urb and industrialized. ${ }^{16}$ However, the gap between different social groups is obvious: while some communities and social groups will equate the quality of life with the provision of all categories of ecosystem services, respectively - supporting, provisioning, regulating and cultural, others are forced to be satisfied only with the basic ones. The relationship between ecosyste services and well-being is not only affected by environmental conditions, but also through social, demographic, political, economic and technological changes which may impact attitude related towards different components of ecosystem services. While evidence of communities' perspectives towards ecosystem services can be found almost everywhere, it is particularly apparent within the transitional settlements (TS), or, according to Trovato, 2015 within the settlements and shelers resur from conflict and natural disasters, ranging fom and durable solutions, where displaced in viduals and cons, whe ditis a indulge with bare essential ${ }^{8}$ Although . cosystor factor that defines the qualty or and especially well-beng, by the most conn surell assessmet, nothly within overall as o a regulating and cultural domain of the accepted ecosystem sem ces typogy. The landscape workshop "e-scape: Transitional settement, the focus of this paper, attempts to investigate does whether landscape design has potential to respond in improving the living conditions within TS, with an additional goal to broaden a metho ology and guidelines of landscape archtectural interventions within them.
LANDSCAPE ARCHITECTURE:

RELATION TO THE QUALITY OF LIFE

From the early beginnings as a profesional discipline, landscape architecture was related to the quality of life in great extent. Subjects of professiona interest of landscape architecture, as well as approaches used to address it, are constantly in close connection with human well-being. While those goals are still predominantly the same, the engagement in the scope and complexity of the discipline is significantly increasing over the years, although still quite varied in different parts of the world. Knowledge bases of landscape architecture practice have expanded as academic knowledge advanced especially in the fields of ecological planning and environmental psychology as well as within cultural processes ${ }^{9}$ The profession is undoubtedly advancing within the specific design skills necessary to meet society's response to environmental change and the need for sustainable development, well as through engagement with society in order to enhance the perception and awareness of landscape identity ${ }^{10}$ Professional engagement in developed shows that the contemporary projects mo for multidisciplinary knowledge, work on different scales, collaboration with ther affint professions, and on hat often require a significant budet. According to Gazvoda, 2002, there Areat amount of different knowledge hat well-educated landscape a must master ${ }^{11}$ Rondom lowe orch nationally awarded projts his statenent, as wre wits interdisciplinary wroject witnessing the iss in change, those that cention cestoms, sustahable development, restoration of derelict spaces and regenIf we look on the strategic, planning
6 Millennium Ecosystem Assessment. 20o5: Chapter 3. Inking Ecosystem Ser
vices and Human Well-being. Ecosysters vices and han wellbeing: multiscale asses
and human sments. Ecosystems and Human Wellbeing: Multiscale Assessments, Volum 7 Literature also recognize the terms "Informal settlement" and "Refugee camps", which is more frequently used
the past. 8 Trovato, M., G. 2016: Landscape in
Emergency, Defining Landscape Democracy Conference Reader. Centre for (a) $\boldsymbol{g}$ Chen, Z., Miller, P. A., Clements, T. L., \& Kim, M. 2017: Mapping research in landscape architecture: Balancing supply
of academic knowledge and demand of professional practice. Eurasia Journal of Mathematics, Science and Technology Education, 13ఠ: 3653-3673. doi:10.1297/

Landscape Architectural Studies to Qua lify for Professional Recognition, 2011, content > uploads > sites > 2012 (retrieved 29 May 2019).

11 Gazvoda, D. 2002: Characteristics of education In Landscape and Urban its ning, Vol. 6o, Issue 2. doi:10.1016/So1692046(02) 00064 -6 aspect, such as green infrastructure witness the same patte of complexity and interdisciplinarity facing the contemporary challenges and rising inclusion of scientific components of affined professions. Besides, recent research focuses on issues connected to the specific social groups, which is reflected in projects such as those related to the therapeutic lan scape design, older persons social wellbeing and indigenous cultural groups. What is common to most of the mentioned project directions? The mentioned activities have several recurrent issues - a) many are increasingly delicate; b) in terms of spatial disposition, majority is allied to the mainstream parts of urban tissue, or the places of special interest, either areas that possess specific, extraordinary qu ities like the nature protection sites an c) most, or at least many of them are still related to the upper- and middleclass social groups. At the same time according to Corner, 2006, "nature", many examples of landscape architectural projects, is mostly represented by a softly undulating pastora scen by a sofly uns is

olent, and soothing a moral as well as a practical antidote to the cors as a prontical and social qualies of the modern city ${ }^{12}$ As such, the open spaces a still very mu such the open spaces are still very mo an am 13 components, and typically related to the upper and midde-class social groups, if we relase he problem to the common, most used threestratum social model. In other words, they are still tackling predominantly urb areas and the life of the urban population within two outlined groups, with only some exceptions. Finally, the last prevailing similarity within the majority of described project directions is corresponding to the question of this paper: they are stiltargeting the quality of life. By doing so, consciously or just guided by the nature of the profession, they are at the same time targeting the ulfilment of ecosystem servic are considered within the indicated plethora of scales and projects goals.

\section{TRANSTHONAL SETILEMENTS:}

RECURRING PHENOMENON

Contrary to the above considerations, there is a layer of marginal social group groups of those who are forced to leave their homes in the times of crises, eithe caused by natural disasters, which we can, according to all warnings related to climate change, expect much more in the near future, but even more of those seeking sanctuary due to the political turbulences and wars. "The scope of this alarming phenomenon is probably best described in a withering statistic that every single minute, 24 people flee their homes... $50 \%$ are younger than 17 years old Currently, there are 65 millio displaced people around the world m.5 $^{15}$ An obvious consequence of those tragic events may be found within TS, which is a relatively new term describing ettlements and shelers resulting fom sellicts ar from emergency response to durable solutions ${ }^{16}$ The prolifertio of nd camp like facilites for mass accoma cas s a process of compilation of refugee ( as cited in Kondyis, 2010$)$ It con as cted in Kandylis, 2016). It can be iving conditios, lat of sacer Jung condtions, lack of space, envronmental problems and othor issues which separate the term landscape from its typical positive imagination. The movements of the people cause creating of spaces that are the result of misuse, waste of natural resources, abnormal production of "rejection", and complaints about the lack of planning the landscape. Usually settled on the outskirts of urban areas, TS a
12 Corner, J. 20o6: Terra Fluxus. Architectural Press, New York. pp. 21-35. 13 Ibid. Status. In Mey, Jacob (ed.). Concise pp. 953. ing the global refugee crisis, http:///ww 16 Trovato, M., G. 2016: Landscape in Emergency, , efining Landscape Demo
racy Conference Reader Centre for Landscape Democracy, Norwegian Un versity of Life Sciences: pp. 117-120. 17 Kandylis, G. 2019: Accommodation Camps in Greece in 2016 . Tournal of Refugee Studies, feyo65. doi: 10.1093/irs/ feyo65 18 Trovato, M., G. 2016: Landscape in Emergency, Defining Landscape Democ-
racy Conference Reader. Centre for Landscape Democracy, Norwegian Un versity of Life Sciences: pp. 117-120. 


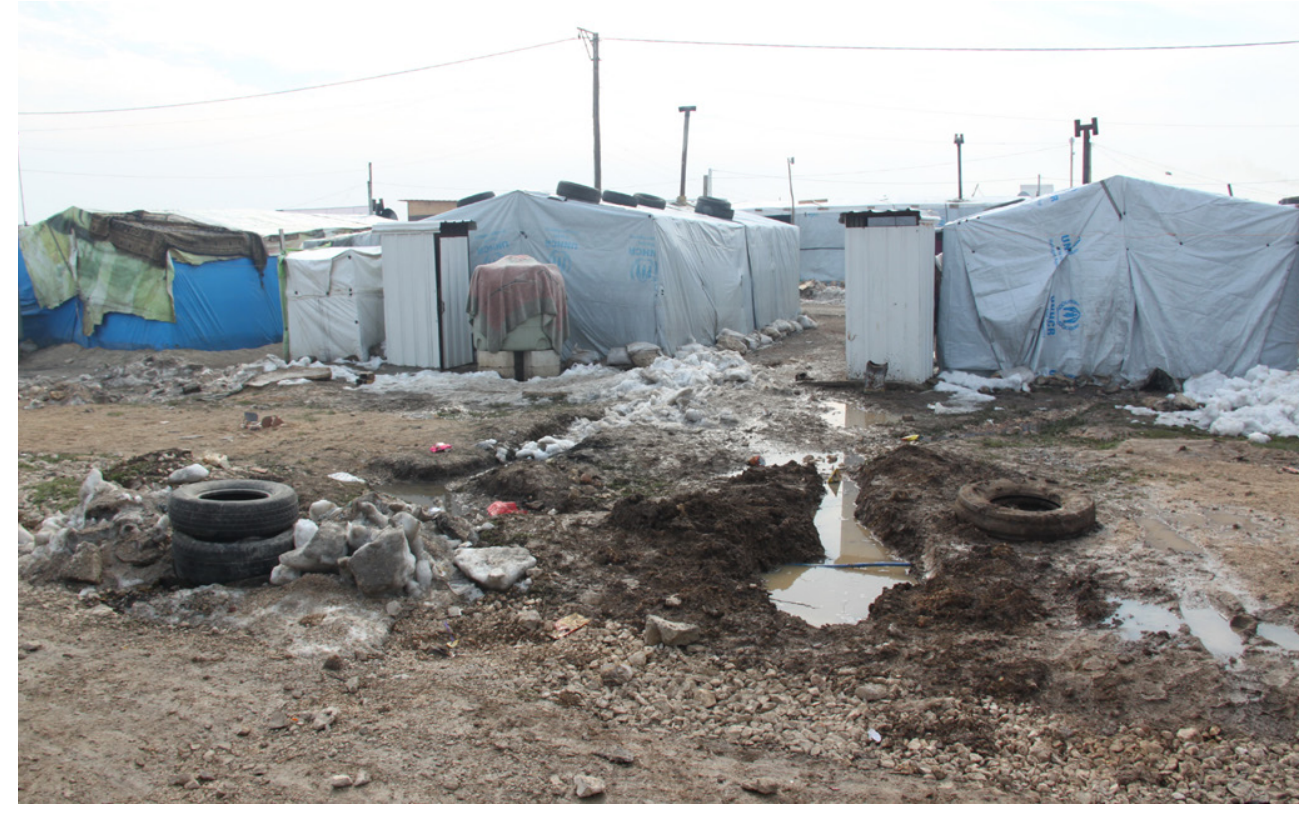

enclosed elements, isolated from the surrounding landscape, sharing only borders shaped by linear landscape elements. The refugee camp is usually positioned between formality and informality, mobility and immobility perm nence and impermanence ${ }^{19}$ (Grberm cited in Kreichauf, 2018). Their intern corna not meet the internation folly foun even ephemeral places, the provisional "bedrooms and hithes" include only elementary infrastructure without clear spation for hierarchy of spaces. Open space is polychere

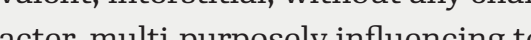
cer, mult purose make people anony ous, replicable, and

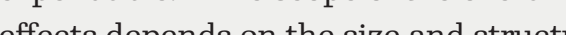
fols depends on the size and structure of in ing of stay, relationships with the local community and the possibility of using resources. In those cases, even just the provisioning and supporting categories of ecosystem services are dependable on the input of external factors, wh the regulating and cultural services seem to be almost out of question. Considering the enormous number of refugees displaced within the Middle

Eastern countries (above all in Jordan, Lebanon and Turkey) and the growing number of migrants in Europe, it is apparent that the TS will be in the focus for a longer time. If we take as an example Syrian war crisis, from its beginning Lebanon became a te shelter for more than a million Syrion efugees ${ }^{22}$ In the situation where with daily challenges of survival is the main concern, environmental issues ely the last one, which esults in many social issues within the TS. Having in mind the scope of the phenon in ens such as Médecins Sans Frontières Architect Without Bo it is justfying to ask is there a place for landreas to ask is thre a place for landcope first glance the rol tecture tecture may exist in those places as well especially if we shift the complexity of contemporary practice for a moment an remind ourselves on the basic question of professional engagement. At the sam time, we should be confident about the role that contemporary landscape archito the mitigation of climatic extremes,

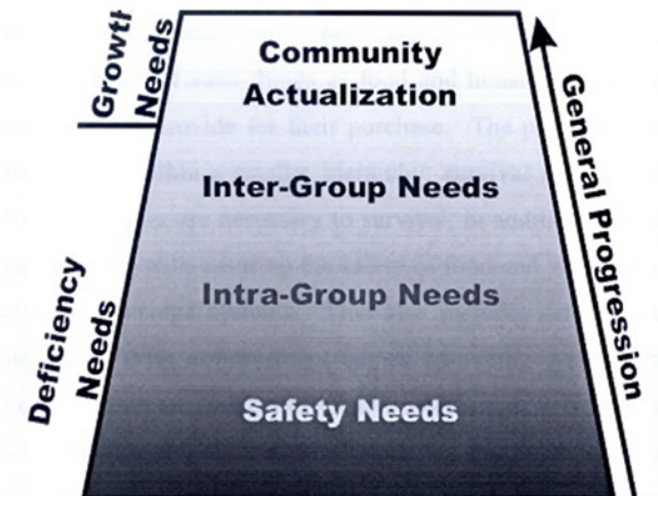

19 Kreichauf, $R$. 2018: From forced migof refugee accommodation in European cities. Comparative Migration Studies. doi: 10.1186//40878-017-0069-8
2o Bshara, K, (n.d.): The spatial practices
in the Palestinian refugee camps, www. in the Palestinian refugee camps, www.
campusincamps.ps/projects/khalduncampusincamps.ps/projects/khala 21 Čepić, S, 2011: Migrants and Landscape: Integration and Impacts Source of Integration and Alienation Source of Integration and Alienation. cin: pp. 236-246.

22019: httpss/detarta, Refugee Situation 2019: https://dataz.unhcr.org/.
ons (retrieved 16 May 2019). /dataz.unhcr.org/.

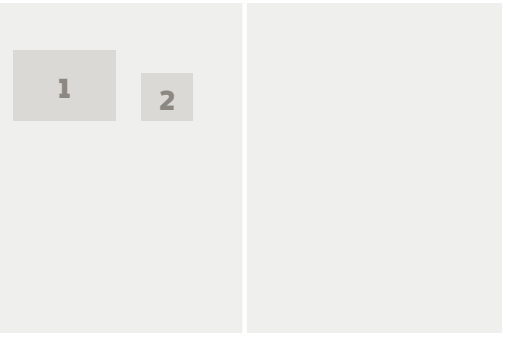

Fig. 1: Al Tyliani Fig. 2: Hierarchy of community (Рното BY LARRY Hierarchy

address environmental impacts such as water pollution or waste management, utilize the benefits of adaptive planting material and address and improve the quality of open space. Or, to summarize can landscape architect fulfil the traditional paradigm - contribute to the improvement of living conditions and quality of life? Finally can the profession influence the reduction of the impacts infure on the environment and int on the the para services concepts from different poles?

\section{“E-SCAPE. TRANSITIONAL} SETTLEMENT" PROJECT

With the aim to approach the problem of the TS from the other perspective Project "e-scape. Transitional Settlement" was organized by the Department of Landscape Design and Ecosystem Management at Amencan University in Beirut (AUB), in collaboration with AUB Centre for Civic Engagement and Community Service, the KAYANY Fou dation and the International Federation of Landscape Architecture (IFLA) within ILA Landscape Architecture Without Borders Working Group. ${ }^{23} \mathrm{Th}$ coordinator of the workshop was assistant professor Maria Gabriella Trovato who led two intensive workshops in Lebanon in January and May 2015. Workshops included a group of international university professors, lecturers and practitioners, together with Lebanese students and local communities, intending to contribute to the improvement of the living conditions in the transitional settlements. At the same time, participants were searching for an wh the role that landscape architecture can have in the settlements that are emering across the globe in a rarer bore " " Project, used as a case study had n a alogy and gudelines of landscape aritectural interventions within the TS.

RROJECT DESCRIPTION AND METHODOLOGY

The research object was Al Tyliani TS, ocated on the edge of the village of Bar Elias in Beqaa Governorate in the Eastern part of Lebanon. The refugee camp covers 9,00o $\mathrm{m}^{2}$, with 63 tents that accommodate 350 inhabitants. The
23 Trovato, M., G. zo16: E-Scape: Australia, httrefagee infur. Landscape Australla, hltps./Mandscapeaustralli.
com/articlese-scape-landscape-and refugee-influxx-1/(retrieved 30 May 2019 
$\begin{array}{ll}\text { Fig. 3: Student's } & \text { Fig. 4: Artificial } \\ \text { tree, at the end of }\end{array}$

$\begin{array}{ll}\begin{array}{l}\text { project proposals } \\ \text { done within the }\end{array} & \text { reedesigned } \\ \text { scope of Studio work } & \text { pedestrian }\end{array}$

$\begin{array}{ll}\text { scope of Studio work } & \text { pedestrian } \\ \text { at AUB, } 2015 & \text { connection at Al }\end{array}$

$\begin{array}{ll}\text { at AUB, } 2015 & \text { connection at Al } \\ \text { (PHOTO BY PROF. } & \text { Tyliani transitional } \\ \text { LARRY HARDER) } & \text { settlement }\end{array}$

(PHOTO BY MARIA
GABRIELLA TROVATO)

layout in the camp and the functionality of architectural and con elements was initially done in accordance with UNHCR principles and guidelines, ${ }^{24}$ while the organized informal settlements are mostly controlled and managed by land or religious associations. ${ }^{25}$ However, pressure coming from an extensive number of dwellers which exceeded minimum spatial standards. influence both interior of the settle ment and the surrounding area, which is suffering from many issues, mainly hygienic and environmental on (Fig. 1). (Landscape) architectural problems are equally numerous, ranging from the rough, impermeable paths, from

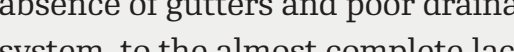
f any public space organised for the cally, there is little inital

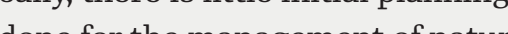
done for the management of natura resources and no awareness of envi-

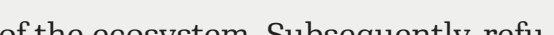
res de gees deplete all resources available and running wastewater and sewage dustates the plant and animal iffe on the site. As a result of overcrowning and the desperate need for space, there are very few green and/or open spaces left in the camp. In addition to the physical effects, all of the mentioned have a psychological effect on refugees, who find themselves disconnected from the land, to which they have a strong connection, coming mostly from the rural areas. ${ }^{26}$
The "e-scape. Transitional Settlement" Project was organized in two connected stages. At the time of the first workshop in January 2015, apart from site visits, significant effort was made to understand the complexity of the situation. Understanding the spatial and socio-cultura context was needed to be extensively analysed both externally, includes driving forces which influence many aspects of settlements functional and spatial organisation, as well as within interna organisation of the community incorporating an overview of the everyday life of the inhabitants. Those aspects are crucial phases related to any intervention within settlements of this kind. The theoretical framework was based on several principles. cally, it was related to the concept of 'Resear throub designing', close to 'Re where the roctivist find general and quatitative knowledge but rathe 'make sef in a qualitative and contextual way ${ }^{27}$ The quarility uility (not ays.

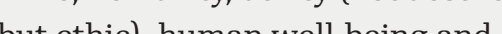
absence che basic criteria established to drive the design process, including the methodologica framework which defines landscape process capable to interrelate (recognize protect, maintain and develop) with the ongoing transformation and the unstable and mutable situations of the teritories affected by the migratory effect. In addition, the general attitude of the

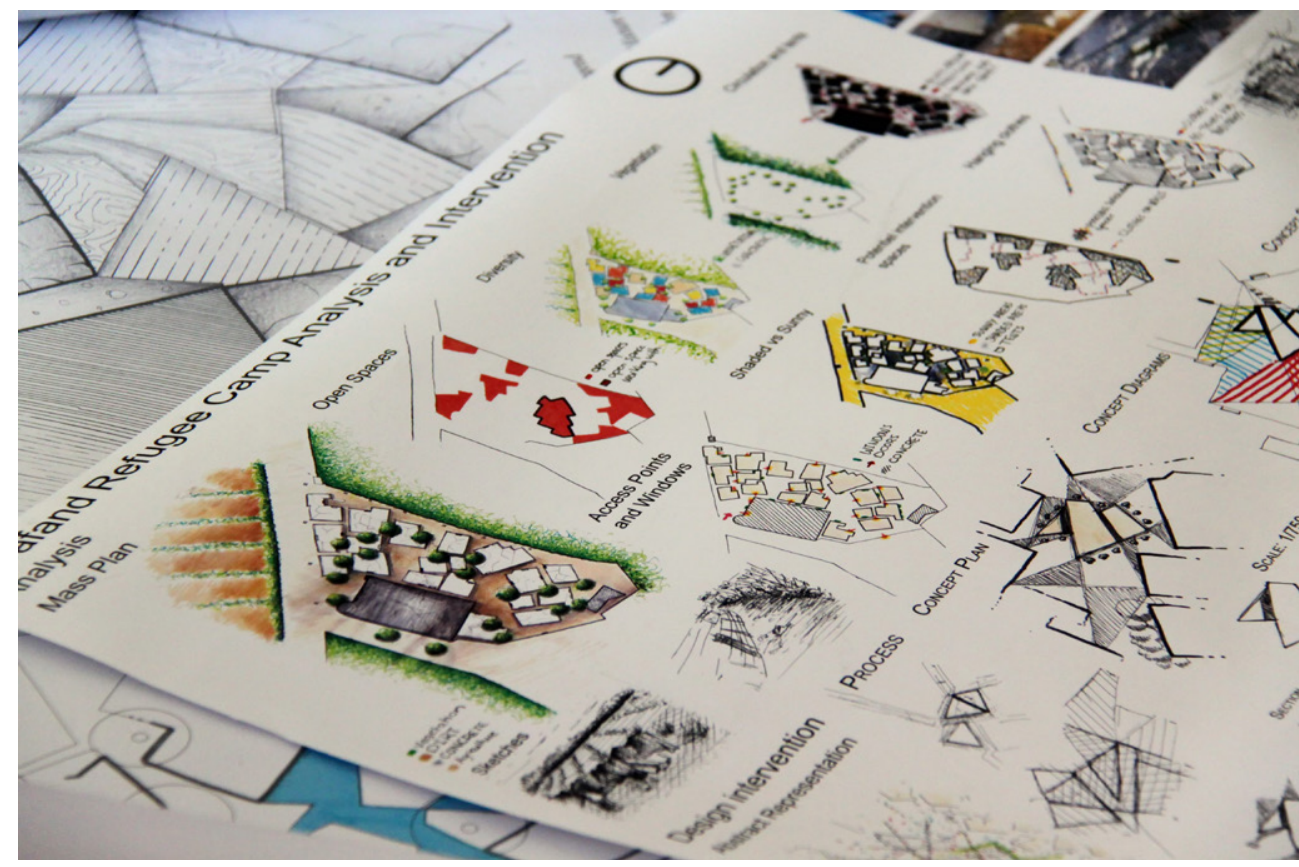

24 UNHCR Emergency Handbook 2019; lements), https://emergency.unhcr.org/ (retrieved 16 May 2019).

ced Migration and New Spatial Practices. [ColHabitation Tactics: Imagining
future spaces in architecture city and landscape, Conference proceedity POLIS University, Tirana, pp. 453-463. 26 Masad D. 2oog: Moving Towards SelfCamps in Lebanon ando Development. A Thesis Presented to the Faculty of California Polytechnic State 27 Lenzholzer, S., Duchhart, I., \& Koh, I. 2013: "Research through designing" in landscape architecture. Landscape and
Urban Planning Volum do: 101016/ 28 Trovato, M., G. 2016: Landscape in Emergency, Defining Landscape Democ racy Conference Reader. Centre for versity of Life Sciences: pp. 117-120. jo $\mathrm{e}$-scape. Transitional settlement Pro ject description. 2015: iflaonline.ora/
uploads/2015/04/e-scape-wonkshol. May-2015 (retrieved 16 May 2019).

project team was that there should serve the people ${ }^{30}$ (Meyer, 1929, as will fulfil consumer needs. This should be no difference between the wellknown design postulate which state that the designers are the servants of the community: whatever we do should cited in Lepik, 2016). In any usual situation, clients employ professionals and have their expectations as how they not be any different when it comes to concerning to

\section{RESULTS AND DISCUSSION}

Much needed meetings with stakeholders, including humanitarian organizations, local authorities, camp owners and TS tenants, were followed by discus sions on setting the methodology for the second workshop, which is planned the second workshop, which is plan Jesign poposls within the Al Tyla TS. The intriews with TS. The interviews with the refugees tation to a new surrounding and most mo to ant enctial and a tant was the observation of everyday practices across the settlement, which led to the understanding of the thin line between public and private space, as one of the crucial aspects that the lan

Following the existing experiences dealing towards improving the living conditions in TS, the team tried to develop short- and long-term solutions that suit the needs of refugees, with a goal to influence living conditions improvement, even in a small scale. Further the group was concentrated ties of the residents. The overall strategy employed by the ( pescibed " wheck to bascs" app compassed the usage of simple, ast solutions, based on identified aps in spatial utilization and finally, luding at least a bit of the local flai to the space, using appropriate materials and plant design. The goal was to increase functionality, usually with solutions which inevitably allowed some overlapping within the time and sequence of functions, resulting in multifunctional spaces. Finally, the attempt to integrate the surrounding landscape have been also considered.

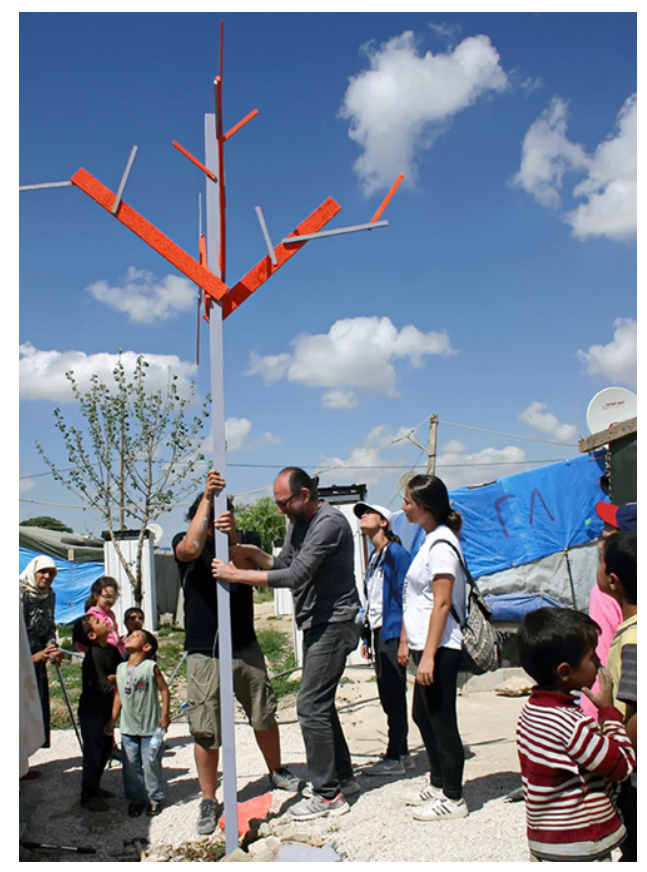

30 Lepik, A. 2016: Think global, build vely involved in socieity. Builders, ed.

31 Briggs, P.D. 19g9: Community Development with Indigenous Communities: ments. A Thesis Presented to The Faculty of Graduate Studies of the University of Guelph, National Library of

2016: Improtow, Dhamma, N., Komlosii, 201l:Impraration between Refugees, Archtects, and Volunteers, Insecurtites TraMoma, https://medium.com/insecurities/ improving-reflage-sellements-collabo ration-between-refugees-architects-and

April 2019). 
pedestrian connection' $\mathbf{B}$

$A^{\prime}$
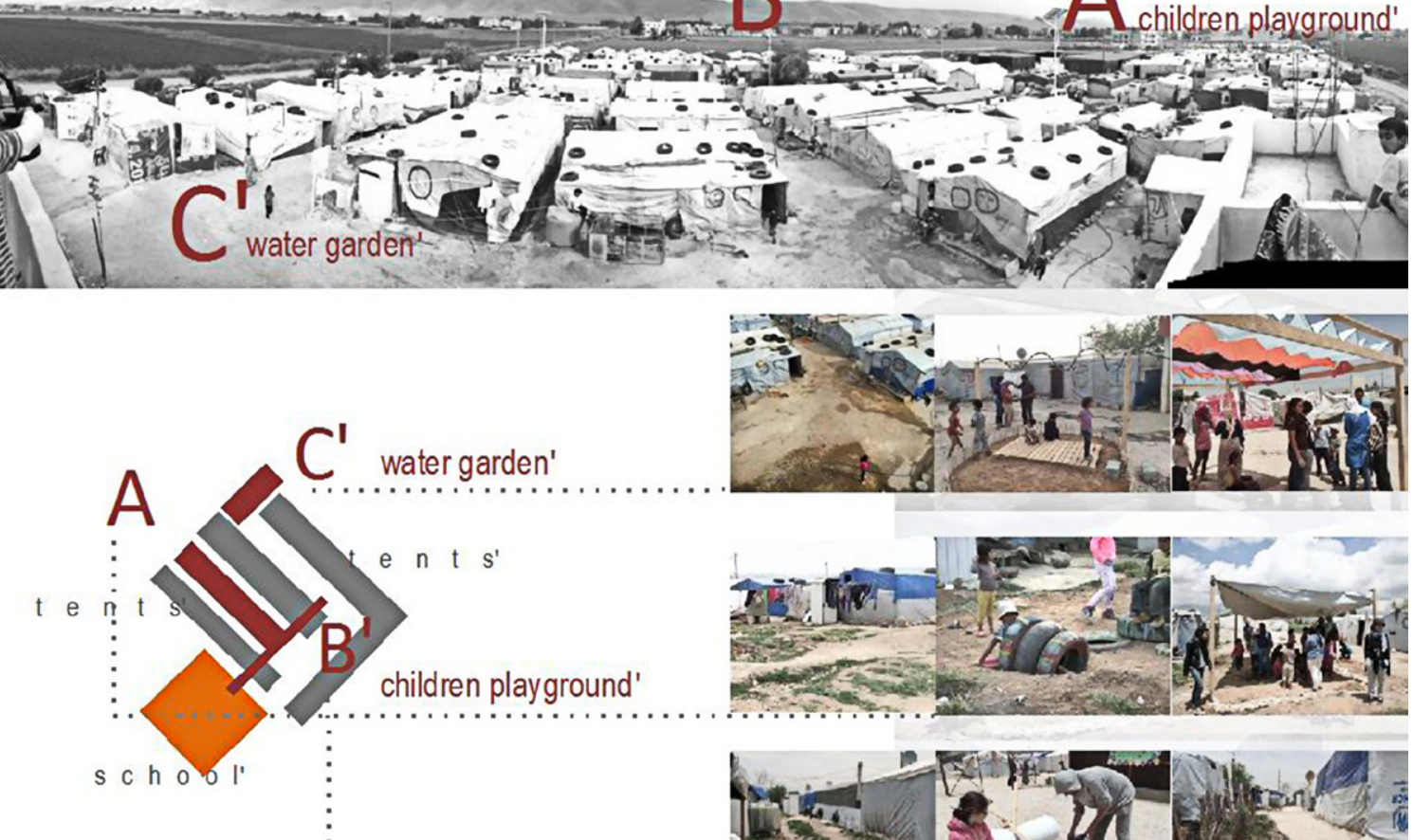

pedestrian connection

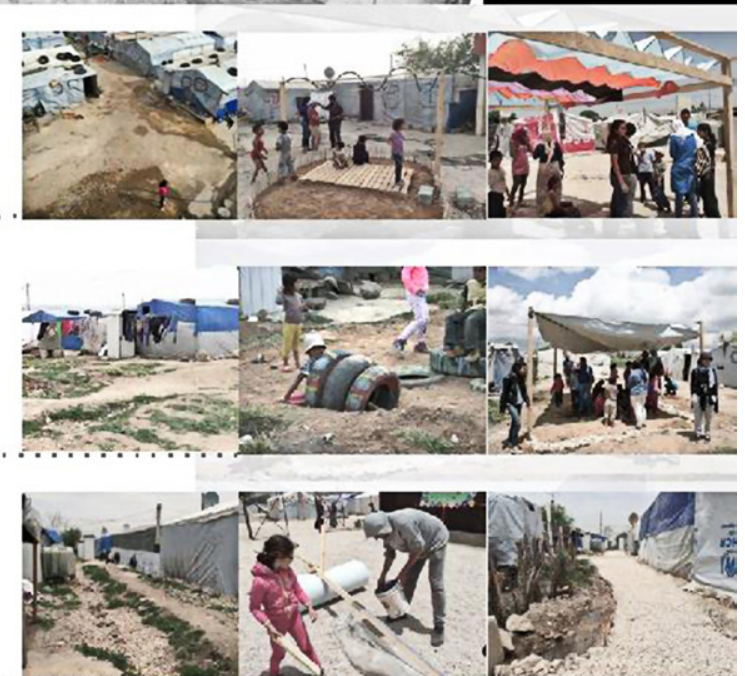

Preparatory work, partially based on the student's project proposals done within the scope of Studio work at AUB (Fig 3) included the discussion concerning the choice discussion tions to be implemented. The decisi the decision, based on the retical promises, led to the intercris spa child playground and the vegetabe garden with water facilites, dividing workshop participants into three group for particular focuses. All interventions primanily implemented landscape desion asproach focused and socio-cultural aspects (addressing cultural realm of ecosystem services), having in mind utilitarian and, in the scope that circumstances allowed, ecological and aesthetic values, mainly through the use of colour through design and construction solutions. The design and especially

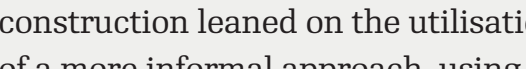
of a more informal approach, using plain solutions which don't require any complex equipmen building and materials. Rather the of that, inexpensive gravel and stones were used to improve one of thes werion grou ger points winth pas space such found directly on the site prod product included the redesign of pedesrian connection with inproved drainage along the walkway, the children playground and a vegetable garden featuring supplemented with shower game are. It is important to emphasize the participation and voluntary involvement during the whole process, from the starting phase by participation in the interviews and discussions, to direct checyexploited to crete the children phe sit additional place for children gathering, of the IS inhabitants, who were active help in a participatory construction process. The joy of the children, who were always around trying to engage was not only significant as an extraordinary day full of play, but also as a process of learning about the organization of the place, with a goal related to the improvement of the quality of life (Fig. 5) ${ }^{33}$ Finally, monitoring of the site after the phase of implementation st though some of the facilities were athough some of the facilities were in experiences within other, similar TS in experiences within other, similar TS projects, demonstrated that some of the the experience and gained knowlized the expets in reper similar to the one that was ing either the productive tilsation of plats, that was part of some of he design proposal

\section{CONCLUSIONS}

In the context of Syrian informal settle ments in Lebanon, the "quality of life", needs to be shifted from the bitter look" of the spaces where any aspect of the design is obsolete, to a paradigm that advocates small, straightforward interventions, engaging the communities of the TS settlements through the partcipatory process. Comprehensive and che thoughtful analyses of the overall context diected towards understanding spatial and sociocultural context both externally as well as internally, within
Fig. 5: Results of "e-Scape: Transitional
settlement" Project: interventions on

three
spaces the physical borders of the settlement is one of the crucial aspects of the overall design process. Identification of those places which can be improved with little input (such as, for example easily constructed drainage canal), would be also of importance for advocating financially feasible proposals. Theoretical framework implies simple design approaches with the usage of ow-cost materials, and me use of antly adherence to the postulate that the designers are servants of the community for this occasion ready to deal with unstable and mutable siturtions. We may also conclude that utilsation of the constructivist research through designing method would be the most likely best way to push forward, as this apprach includes not only sitesecific context, but also takes into In the social circun In the fis it wiond only about the on the significan "pulic" sas ma bave eve in pla "pulike TS are as the ne even in places like even the mininum dosn't respect ven the lished by UNHCR Guidelines for Camp planning standards. On the other hand, mentioned guidelines are far tions reled to the rembson of 作 seses, that could support provision of elementary ecosystem services, that the locations for those functions
33 Trovato, M. G. 2017: Landscape and Syrian Inform practical intervention on Scenario Journal o6: Migration, https:// and-displacement//rretrieved 16 April 34 UNHCR Camp Planning Standards (Planned Settlements), within camp setlement size recommends minimum sur face area is 45 square meter per person, space (UNHCR Emergency Handbook, space
2019 . 
could be found in many cases. This gap should be emphasizing, as those places are especially important, being able to provide opportunities for children to grow and develop in at least a bit use friendly environment. If we add that majority of established TS are not of a short-term nature, but places where people are forced to live for years, ${ }^{3}$ reasons for including consideration related to the embodiment of open spaces may sound more grounded. Equally important would be to think about the role and responsibility the landscape architects have within present-day society, as there is much more to offer, even with the mentione broadening of the scope of work. This ba marginal societies and lowt within social groups, where rotion-class and simple design solution, grounded in ecological approaches that ensure ins gh the appropriate of biological, land, water and atmospheric systems $\mathrm{s}^{36} \mathrm{can}$ be quite valuable. Exactly those knowledges are an integral part of the landscape architectural profession. Those solutions can easily match the framework of ecological services, especially those within the regulating and cultural categories, the most overlooked ones withi the transitional settlements. Indicated categories are to a significant extent achievable with the lowest input, but capable to make a difference and at least in some portion increase quality of life of TS dwellers. Although ther are still very few examples linked to the research on the quality of life of TS, and there is an existing gap within the assessment of the actual, on-sight contributions within the projects of this kind. However, further research would be needed to determine the actual, methodologically grounded benefits of landscape architecture projects within the TS, such as, for example, Relative Valuation of Multiple Ecosystem Services method (RESVI) ${ }^{37}$ (Jordan et al., as cited in Dawson et al., 2015). Despite the fact that every transtional settlement has his own characteristic, presenting a "story of his own", lessons learned from the example of e-Scape Project, albeit limited due to the time and funding constrains, provided an insight to the landscape design potentia in setting out new approaches and applicable methodologies, which can be beneficial to those facing similar challenges. Although sometimes only temporarily. approaces of this kind can prorarily the awareness, knowledge, innovation nd management to the inhabitants and if solity o elementary ecosystem services.

\section{Acknowledgements}

The "e-scape: Transitional Settlement" workshop and research were supported y Department of Landscape Design an cosystem Management at American niversity in Beirut (AUB), in collaboraion with AUB Centre for Civic Engagement and Community Service, the KAYANY Foundation and the International Federation of Landscape Architecture (IFLA). We are especially thankful to Maria Gabriella Trovato, PhD Assistant Professor, American University of Beirut, for the initiative and leadership of the "e-scape: Transitional Settlement" Project.
35 As of end-2015, the median duration of exile stands at 4 years, i.e. half of the refagess worlduide have spent 4 years
or less in exile (Devictor, Quy-Toan, 2016 https://blogs.worldbank.org/devapeace/ how-many-years-do-refugees-stay-exile, Architectural Education, 2012: http://ifla online.org/wp-content/uploads/2014/11/ IFLA-Charter-for-Landscape-Architectu ral-Education-Revised-2012.pdf
37 Dawson, N., \& Martin, A. 2015: Assessing the contribution of ecosystem ser-
vices to human wellbeing: A disaggrega ted study in western Rwanda. Ecological Economics 117: 62-72. doi: 10.1016/.ecole.
TÁJÉPÍTÉSZET ÉS ÉLETMINŐSÉG -ÉLETMINŐSÉGI KÉRDÉSE AZ ÁTMENETI TELEPÜLÉSEKEN

A különböző társadalmi és politikai körulmények között élő csoportok különbözőképpen határozzák meg az életminőséget és jólétet, melyben az ökoszisztèma által nyujtott szolgátatások is jelentős szerepet kapnak. A tájépitészet a kezdetektől fogva az emberi jólétet és életminőséget helyezi a tevékenysége középpontjába, s az idók során ennek megfelelően alakultak a szakmai feladatok és megközelitési módok. Azonos célok mellett az elmúlt évtizedek során jelentỏsen megváltoztak a szakmai feladato bek lettek; a hagyományos hozzááll a szakmai feladatokat átszövő paradigma változatlan maradt: a tájépítészet mindenkori hivatása, hogy javítsa az életkörülményeket és az életminőséget. A legtöbb projekt a városi teriletekkel, a városi lakosság életminöségének javitásával foglalkozik, s ezek inkább a felső és középosztályok számára jelentenek minőségi javulást. A fenti megfontolásokkal szemA fenti megfont vassok szemsadalmi csoportok, amelyek válságok, természeti latasztrófák vagy politikai zavarǵ́s és hábońk

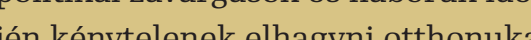
jen kenyte s me súnos or jelenn sún jelennek meg, reszukre menekuttáborokat vagy átmencte telueseket hoznak Itre. Ezeket a táborokat, településeket általában rossz elet-
körülmények és helyhiány jellemzik, és müküködésük közben számos környezeti problémát okoznak. Az alapvető életfeltételek biztosítása melett az ökoszisztéma-szolgáltatások (szabalyozó, kulturális funkció) egyértelműen háttérbe szorulnak.
Ez a cikk az ,e-scape. Atmeneti település "projektről szól, amelyet a Bejrúti Amerikai Egyetem Tájrendezési es Okoszisztema-Menedzsment Tanszéke szervezett a Tajejpiteszek Nemzetközi Szôvetségével - IFLA - együtmüködésben. A projekt célja az volt, hogy hozzajaruljon az atmeneti településeken az életkörülmények javításához, beleértve az elemi ökoszisztema-szolgaltatásokat is, továbbá, ho kialakítsa a konfliktusok és a természeti katasztrófák miatt létesített átm-neti településeken alkalmazható tájéptészeti beavatkozások módszertanát az ahhoz kapcsolódó útmutatásokat.

A kutatási terület a Libanon keleti részén, Beqaa kormányzóságban taláható Al Tyliani TS volt. A menekülttábor gooo $\mathrm{m}^{2}$ területü, 63 sátorral, $35 \circ$ féröhellyel. A tábort az UNHCR alapeveinek figyelembevételével alakítottá ki. A települést főként a földtulajdonosok vagy vallási szervezetek ellenőrzik és kezelik. A nagy számú lakosság miatt azonban a minimális terileti elő́ŕśsok sem tudnak érvényesü és számos higiéniai és környezetvédelmi problémával kell szembe nézniïk. A környezeti, éṕtészoci nézmák isen komolyak, kezdve az átjérhatatlan útvonalaktól, a csatońc hiányától és a rossz vízelvezető rendszertőll exészen az alapvető társadal

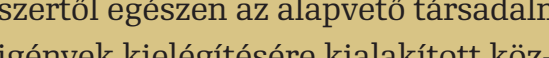
terïletek szinte teljes hin

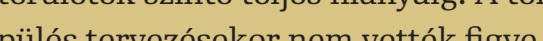
per a tor lembe a kornyezet adottságokat, nem foglak az konyezetvedelmi kerdoseknel, s forent nem az okosziszten fenntarthatoságával. A nagy számú menekult hamar kimeritette az osszes rendelkezésre alló erơforrást, a vizhiany ess a kezeletelen szennyviz elpusztitotta a telep novenny- es âllatvilagáat. A túlzsúfoltság és az egyre nagyobb kevés zöldfelület és szabadtér maradt.
A projekt során több workshopo tartottak a helyszínen. Az első alk lommal a körülmények megismeresén, felmérésén volt a hangsúly. A projekt ideje alatt több találkozót tartottak az erintettekkel: humanitárius szervezetekkel, helyi hatóságokkal, a táborok tulajdonosaival és a TS bérlóivel. Ezt kôvetoon megbeszéléseket folytattak a második mühely módszertanannak meghatározásáról, amely a tervezési javaslatok tényleges megvalósitását foglalta magában. A menekültekkel készitett interjúk jelentették az egyik alapot az igények megismeréséhez, ideértve a társadalmi és környezetvédelmi kérdéseket is. A projekt résztvevői maguk is végeztek megfigyeléses vizsgálatot a település mindennapi életének, a közterek és magánterek használatának megismerésére, s a két használati forma közötti keskeny határmezsgye értelmezésére. Ezek a szempontok kulcsfontosságúnak bizonyultak a TS tájképe esetében.

A Libanonban lévő́ átmeneti szíriai településekkel összefüggésben az aéletminőséget" el kell válasstani a terek megielenésétöl". A tér- és formatervezés bármely aspektusa elavult, sezért támogatni kell a kicsi, egyértelmü beavatkoźsokat, melyek mán

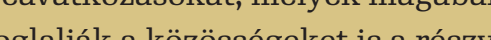

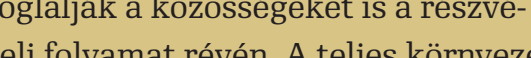
tfogó tegrocio-kulturatis kntese a terbell tésével, a komplex terveź́si folyma gyik kritikus lépése. 